\title{
САМООРГАНІЗАЦІЯ ПЕПТИДНИХ НАНОСТРУКТУРОВАНИХ НАПІВПРОВІДНИКІВ - ПОТЕНЦІЙНА ОСНОВА ПОДОЛАННЯ РОЗРИВУ МІЖ НЕОРГАНІЧНИМИ ТА ОРГАНІЧНИМИ ЕЛЕМЕНТАМИ ЖИВОГО
}

\author{
О. П. Мінцер, В. М. Заліський \\ Національна медична академія післядипломної освіти імені П. Л. Шупика
}

\begin{abstract}
Дослідження присвячено проблемам використання біологічних інструментів для нанотехнологічних застосувань, не пов'язаних із біологією, таких як мікроелектроніка та наноелектроніка, мікроелектромеханічні та наноелектронні системи. Здійснено узагальнення досвіду використання біологічних інструментів і каркасів для створення пептидних наноструктурованих напівпровідників. У результаті дослідження з'ясовано, що забезпечення більшої селективності, яке проявляється білками в біологічній хімії, можна досягти одночасним використанням декількох неорганічних матеріалів для паралельної конструкції, наприклад, як перша комбінація самозборки на основі ДНК і молекулярного розпізнавання пептидів для демонстрації візерункової синтетичної біомінералізації. Короткі пептиди, що містять ароматичні амінокислоти, можуть самоорганізовуватися в різні надмолекулярні структури, які залишаючись кінетично та термодинамічно стабільними, утворюють агрегати дифенілаланіну або фенілаланін-триптофану. Різні методи утворення агрегатів можуть бути використані для ініціації специфічної фуннкціоналізованої організації наноструткурних блоків із точно настроєною структурною геометрією та контрольованими напівпровідниковими характеристиками. Такі методи налаштування включають мікрофрлюїдику, молекулярну модифікацію, хімічні та фрізичні методи осадження з пароподібного стану, збірний стратегічний метод одночасного укладання, а також використання зовнішнього електромагнітного поля. Залучення теорії молекулярної щільності показало, що великі спрямовані ароматичні амінокислотні при взаємодії з мережами, які зв'язують водень, призводять до утворення квантово замкнутих областей в органічних наноструктурах, які лежать в основі молекулярного походження їх напівпровідності. Останні дослідження додатково виявили деякі фізико-хімічні особливості біоінспірованих надмолекулярних органічних напівпровідників, включаючи стійкі спектри поглинання, характерні для одновимірних квантових точок, або двомірних квантових свердловин, емісію сротолюмінесценції оптичних хвилеводів, залежну від температури електропровідність, а також сегнетоелектричні (п'єзо- та піроелектричні) властивості.
\end{abstract}

Ключові слова: молекулярна самозборка, структурна ДНК-нанотехнологія, молекулярне розпізнавання, олігонуклеотид, олігопептид, самозборка фрталоціанінів і порфіразинів, біоінспіровані матеріали.

\section{SELF-ORGANIZATION OF PEPTIDE NANOSTRUCTURED SEMICONDUCTORS - A POTENTIAL BASIS FOR BRIDGING THE GAP BETWEEN INORGANIC AND ORGANIC LIVING ELEMENTS}

\author{
O. P. Mintser, V. M. Zaliskyi \\ Shupyk National Medical Academy of Postgraduate Education
}

Background. Research is devoted to the problems of using biological tools for non-biological applications of nanotechnology, such as microelectronics and nanoelectronics, microelectromechanical and nanoelectronic systems. The purpose of the study was to summarize the experience of using biological tools and scaffolds to create peptide nanostructured semiconductors.

Materials and methods. Results. Providing greater protein selectivity in biological chemistry can be achieved by the simultaneous use of several inorganic materials for parallel construction, such as, for example, the first combination of DNA-based self-assembly and molecular recognition of peptides to demonstrate pattern-synthesis synthesis. Short peptides, in particular containing aromatic amino acids, can self-organize into various supramolecular structures that remain kinetically and thermodynamically stable to form diphenylalanine or phenylalanine-tryptophan aggregates. Various methods of aggregation can be used to initiate specific functionalized organization of nanostructured blocks with fine-tuned structural geometry and controlled semiconductor characteristics. Such tuning methods include microfluidics, molecular modification, chemical and physical vapor deposition methods, an integrated strategic simultaneous stacking method, and the use of an external electromagnetic field. Involvement of the theory of molecular density showed that large directional aromatic amino acid interactions of hydrogen - bonding networks lead to the formation of quantum - closed regions in the organic nanostructures underlying the molecular origin of their semiconductivity.

Conclusions. Recent studies have additionally identified some of the physicochemical features of bioinspired supramolecular organic semiconductors, including stable absorption spectra characteristic of one-dimensional quantum dots or two-dimensional quantum wells (piezo- and pyroelectric) properties.

Key words: molecular self-assembly, structural DNA nanotechnology, molecular recognition, oligonucleotide, oligopeptide, self-assembly of phthalocyanines and porphyrazines, bioinspired materials. 


\title{
САМООРГАНИЗАЦИЯ ПЕПТИДНЫХ НАНОСТРУКТУРИРОВАННЫХ ПОЛУПРОВОДНИКОВ - ПОТЕНЦИАЛЬНАЯ ОСНОВА ПРЕОДОЛЕНИЯ РАЗРЫВА МЕЖДУ НЕОРГИНИЧЕСКИМИ И ОРГАНИЧЕСКИМИ ЕЛЕМЕНТАМИ ЖИВОГО
}

\begin{abstract}
О. П. Минцер, В. Н. Залесский
Национальная медицинская академия последипломного образования имени П. Л. Шупика

Исследование посвящено проблемам использования биологических инструментов для нанотехнологических приложений, не связанных с биологией, таких как микроэлектроника и наноэлектроника, микроэлектромеханические и наноэлектронные системы. Проведено обобщение опыта использования биологических инструментов и каркасов для создания пептидных наноструктурированных полупроводников. В результате исследования установлено, что обеспечение большей селективности, которое проявляется белками в биологической химии, можно достичь одновременным использованием нескольких неорганических материалов для параллельной конструкции, например, как первая комбинация самосборки на основе ДНК и молекулярного распознавания пептидов для демонстрации узорной синтетической биоминерализации. Короткие пептиды, содержащие ароматические аминокислоты, могут самоорганизовываться в различные надмолекулярные структуры, оставаясь кинетически и термодинамически стабильными, образуют агрегаты дифенилаланину или фенилаланин-триптофрана. Различные методы агрегатообразования могут быть использованы для инициации специфической функционализированной организации наноструктурних блоков с точно настроенной структурной геометрией и контролируемыми полупроводниковыми характеристиками. Такие методы настройки включают микрофрюидику, молекулярную модифрикацию, химические и фризические методы осаждения из парообразного состояния, сборный стратегический метод одновременного заключения, а также использование внешнего электромагнитного поля. Привлечение теории молекулярной плотности показало, что большие направленные ароматические аминокислотные при взаимодействии с сетями, которые связывают водород, приводят к образованию квантово замкнутых областей в органических наноструктурах, лежащих в основе молекулярного происхождения их полупроводниковости. Последние исследования дополнительно обнаружили некоторые физико-химические особенности биоинспирированных надмолекулярных органических полупроводников, включая устойчивые спектры поглощения, характерные для одномерных квантовых точек, или двухмерных квантовых скважин, эмиссию фотолюминесценции оптических волноводов, зависящую от температуры электропроводность, а также сегнетоэлектрических (пьезо- и пироэлектрические) свойств.
\end{abstract}

Ключевые слова: молекулярная самосборка, структурная ДНК-нанотехнология, молекулярное распознавание, олигонуклеотид, олигопептиды, самосборка фрталоцианинов и порфиразинов, биоинспирированные материалы. 
Вступ. Напівпровідники відіграють центральну роль у сучасній оптиці та електроніці. Звичайні неорганічні напівпровідникові матеріали мають певні оптичні властивості, пов' язані зі складністю процедур вирощування кристалів, використання токсичних металів тощо [19], особливо в сучасних галузях матеріалознавства, таких як створення нанорозмірних об'єктів із біологічними елементами та із застосуванням технологій «знизу-вгору» для їх виготовлення [2, 4].

Органічні полімерні напівпровідники (на основі самозборки фталоціанінів і порфіразинів) [36] частково дозволяють долати деякі недоліки та визнані в якості потенційних альтернатив. Формування добре впорядкованих наноструктур шляхом самозборки різних органічних і неорганічних будівельних блоків може стати потенційно корисним у біології і хімії. Серед усіх органічних будівельних блоків пептиди є однією 3 найбільш перспективних платформ завдяки їх біосумісності, хімічній різноманітності та подібності до білків. Останні досягнення в області самозборки пептидів і формування різних наноструктур, таких як трубчасті структури, волокна, везикули, сферичні та стрижневі структури дозволили розглянути інші потенційні можливості застосування в області доставки лікарських засобів (ЛЗ) і тканинної інженерії.

Небіологічна природа звичайних неорганічних напівпровідникових матеріалів не дозволяє здійснювати створення багатофункціональних сполучених електронних пристроїв із біологічними структурами (на основі електроактивних зв'язків) для потреб біомедицини (зокрема, тканинної інженерії) [2, 7]. Перспективним кандидатом для біоінспірованих і високоміцних нанооб'єктів являється сімейство самозборних наноструктур, що містять короткі відрізки пептидних молекул.

Мета роботи: узагальнити досвід використання біологічних інструментів і каркасів для створення пептидних наноструктурованих напівпровідників.

Результати та їх обговорення. Біоінспірована (біологічно-орієнтована) надмолекулярна хімія може дозволити забезпечити кращий інтерфейс між напівпровідниковими (неорганічними) та біологічними (органічними) властивостями матеріалів. Зокрема, прості пептидні біоконструкції з внутрішньою здатністю до трансформації при самозборці в упорядковані наноструктури є перспективними кандидатами для створення біоінспірованих і міцних нанорозмірних напівпровідників (рис. 1) [16, 22].

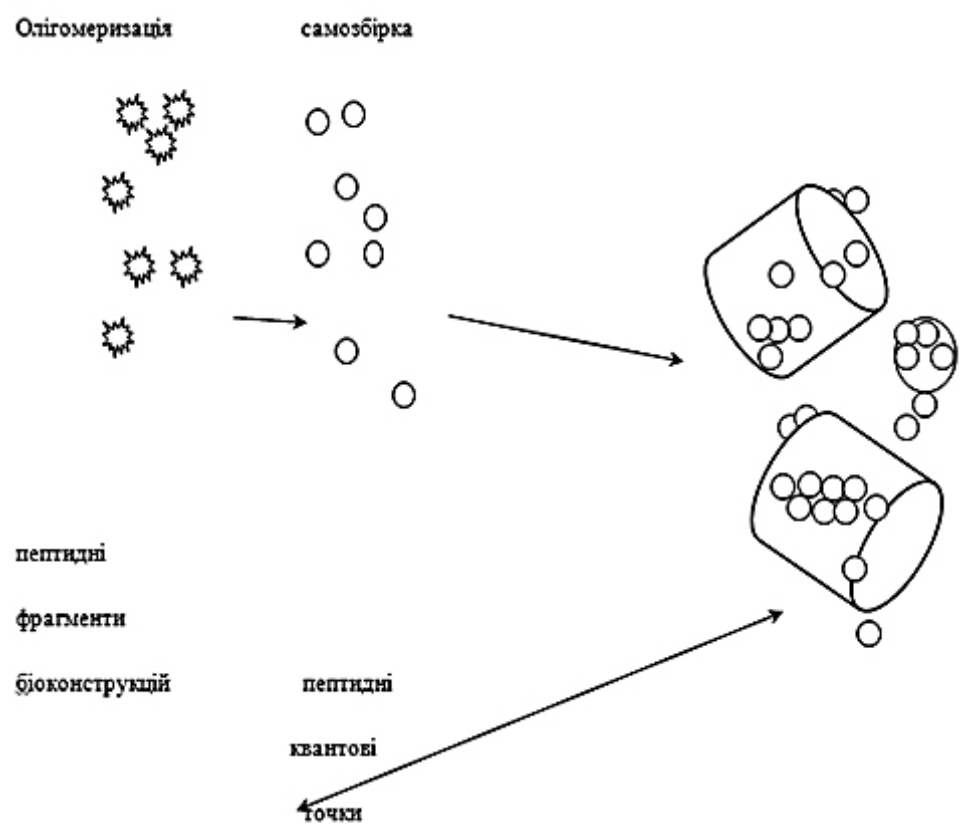

пептидні

вапівпровідникові

суперструхтури

Рис. 1. Пептидні самозборні конструкції з внутрішніми напівпровідниковими властивостями (органічні напівпровідники) 
Самоорганізація (самозборка, «self-assemble») пептидів в упорядковані наноструктури зберігає їхні фізико-хімічні властивості. Інтеграція пептидів із хімічними сполуками, такими як периленімідні фрагменти («perylene diimide moieties») [14, 15] дозволяє створювати нові продукти із заданою структурною геометрією та стійкими напівпровідниковими характеристиками, що забезпечує їхнє використання в біомедичних і технологічних програмах.

У порівняно недавніх дослідженнях виявлено власні напівпровідникові, оптичні властивості деяких природних довго ланцюгових білкових структур [11]. Зокрема, агрегація амілоїдних фібрилярних утворень, що володіють напівпровідниковими властивостями, виявлялася при впливі світлом із довжиною хвилі $\lambda=405$ нм у процесі самозборки. При цьому, ауто флуоресценція, що виникала, допомагала позиціонувати in vivo ці фібрилярні білки, пов'язані з нейродегенеративними захворюваннями [28].

Самозборні біоконструкції з дуже коротких пептидних ланцюжків, у тому числі, амілоїдогенних білків, мають напівпровідникові властивості [31], на тлі їхньої «жорсткої» самоорганізації (надійної механічної жорсткості) [5], та помірної цитотоксичності [35], демонструючи цим задовільну біосумісність надмолекулярних структур [30], а також - окислювальну стабільність [32]. При цьому, простота та низька вартість синтезу дозволяють сподіватися на широке застосування пептидних напівпровідників для виготовлення функціональних біологічних наноматеріалів, що самозбираються [33].

Відомо, що напівпровідникові властивості суттєво пов'язані зі структурою матеріалів [23]. Тому, численні наноструктури, утворені в результаті самостійного складання, зокрема, за допомогою коротких пептидних ланцюжків, можуть мати властивості універсальних напівпровідникових елементів [6].

Так, ароматичний дипептид-дифенілаланін бере участь у стійкій самоорганізації/зборці напівпровідникових наноструктур [25, 26]. Самозборка дифенілаланіну в подальшому могла би бути модульована (доповнена) цілим спектром упорядковано збудованих пептидних наноструктур у вигляді стрижнів («nano rods»), сфер («nano spheres»), волокон («nano fibers»), трубок («nano tubes»), кристалічних плівок («plate-like crystals»), методами розчинення, випаровування, сушіння, заморожування, оброблення в електричному та магнітному полях [12, 17, 37].

Розміри нанотрубок дифенілаланіну безпосередньо залежали від вихідної концентрації цього пептиду [38]. Застосування мікрофлюїдної технології дозволило в реальному масштабі часу здійснювати концентраціє-залежне нарощування та динамічну усадку структури дифенілаланінових нанотрубок [9].

Порівняно нова біотехнологія спільного й одночасного укладання коротких пептидних ланцюжків («coassembly strategy») дифенілаланіну та трифенілаланіну дозволила здійснити щільну упаковку гідрофобних бічних ланцюгів нанотрубок (уникаючи контактів із молекулами води) та успішно контролювати довжину Nano tube-структур [20].

Схильність до самозборки дифенілаланінових наноструктур підвищувалася методом хімічної кон’югації («chemical conjugation») [33], тобто заміни пептидів (дифенілаланіну та трифенілаланіну) молекулами порфірин - заміщених фрагментів («porphyrin — substitend nuotit»). При цьому, багатоетапний процес утворення органічних наноагрегатів здійснювався, але за так званому покроковому правилу Оствальда («Ostvald’s step rule») [24], відповідно до якого процес розвивається через систему «переходів» послідовно від наносфер і нановолокон до нанотрубок.

Необхідно відзначити, що заміна фенольних кілець азотистих основ дозволила виявити нову сім’ю біоінспірованих (біологічно-подібних) будівельних білків (що включають пептидні ДНК на основі агрегованих нуклеїнових кислот, які самоорганізовуються), котрі здатні самостійно включатися в добре організовані та щільноупаковані наноструктури, завдяки координаційному впливу Уотсон-криковських водневих зв'язків $[1,10]$. Самозборка пептидних нуклеїнових кислот (що $\epsilon$ олігомерами, фосфатний остов яких замінений короткими молекулами - імітаторами ДНК) зумовила появу в наноагрегатів пептидних нуклеїнових кислот таких оптичних властивостей як індукована струм-залежна електролюмінесценція, а також (пов'язана зі збудженням світлом) флуоресценція у видимій області спектра [10].

Активне вивчення особливостей самозборки та просторової молекулярної геометрії коротких пептидних наноструктур спрямовано на виявлення механізмів формування їхніх напівпровідникових властивостей. Виявилося, що ароматичний дипептид дифенілаланін може функціонувати 
як квантова точка в процесі самозборки. При цьому короткі пептидні наночастинки (квантові точки) можуть служити в якості елементарних будівельних блоків поряд із пептидними нанотрубками [8]. Тобто процеси «зборки-самозборки» відбуваються за участю їх чергування, що і може служити обгрунтуванням механізму напівпровідникових властивостей пептидних наноструктур. Інші автори вважають, що в основі молекулярного механізму біологічної напівпровідності лежить стан квантово-розмірних структур у регіонах із локалізованим перенесенням протонів [29] і перерозподіл (спрямоване перенесення) водневих зв’язків [34]. Отже, напівпровідникові властивості пептидних наноструктур можна змінити шляхом посилення ароматичних взаємодій або інгібування водневих зв’язків у процесі самозборки.

Одноосно орієнтовані пептидні надмолекулярні напівпровідникові наноплівки в процесі самоорганізації можуть передавати фотони безперервного світлового потоку, що дозволяє їм виконувати функцію активного оптичного хвилеводу [39] та пропонує розширення їхніх функціоналізацій для застосування як фотоелементів сонячного світла, а також - як оптичного кабелю [34].

Спрямоване перенесення водневих зв’язків i мережева взаємодія ароматичних амінокислотних фрагментів демонструє, що пептидні наноструктури (нанотрубки), які самозбираються, мають здатність до певного вирівнювання диполів [18], що може призводити до спонтанної поляризації, котра лежить в основі їхньої сегнето-електричних властивостей [21].

Самоорганізація пептидних нанотрубок і пептидних нанострижнів демонструє посилення генерації поверхневих зарядів (наведена електрична поляризація) та п’єзоелектричну активність пептиду дифенілаланіну [27], що відкриває широку перспективу створення нанорозмірних п’єзоелектричних матеріалів на основі використання біоактивних трубчастих наноструктур, потенційно сумісних із тканинами людини.

Наведена електрична поляризація завдяки зборці коротких пептидних наноагрегатів, в умовах їхнього розміщення на підкладці, може призвести до створення чутливих і універсальних біодатчиків мультиплексного виявлення цільових патогенів на чіпі, зокрема на основі інтеграції металів із нанопептидами, що володіють високою прихильністю до іонів свинцю [13].
Отже, великі експериментальні та теоретичні дослідження показали, що напівпровідникові властивості, притаманні окремим пептидним наноструктурам із специфічними фізико-хімічними властивостями, які дозволяють перетворювати біологічно-подібні об’єкти в функціональні матеріали. Оскільки вони відрізняються екологічною стійкістю та морфофункціональною гнучкістю, надмолекулярні наноматеріали також можуть служити перспективною альтернативою широко застосовуваним неорганічним аналогам.

Біоінспіровані (біологічно-подібні) матеріали на основі самоорганізації пептидних наноструктур дозволяють їм «наводити мости» між неорганічним світом напівпровідників і біологічними системами, роблячи їх корисними для застосування в фундаментальних біологічних дослідженнях i в медичній науці.

Короткі пептидні самозбірні наноструктури можуть дозволити активно розвиватися новому напряму пошуків особливостей білкової напівпровідності в фізіології та патофізіології. Наприклад, дослідження взаємозв’язку між напівпровідниковими властивостями негативно орієнтованих поліпептидів (у результаті неправильного згортання («misfolding»)), що характерні для різних нейродегенеративних захворювань у людини, допоможе уточнити механізми їхнього розвитку та розробити адекватні програми лікувальних заходів.

Нарешті, самоорганізовані короткі напівпровідникові пептиди можуть бути використані в розробках нанобіороботів, направлено працюючих всередині біологічних систем, що дозволило б у режимі реального часу контролювати порушення метаболічних процесів в організмі в умовах персоналізованої медицини [3].

Висновки. 1. Забезпечення більшої селективності, що проявляється білками в біологічній хімії, можна досягти одночасним використанням декількох неорганічних матеріалів для паралельної конструкції, як, наприклад, перша комбінація самозборки на основі ДНК і молекулярного розпізнавання пептидів для демонстрації візерункової синтетичної біомінералізації.

2. Короткі пептиди, що, зокрема містять ароматичні амінокислоти, можуть самоорганізовуватися в різні надмолекулярні структури, які залишаючись кінетично та термодинамічно стабільними, утворюють агрегати дифенілаланіну або фенілаланін-триптофану. Різні методи агрегатоутворення 
можуть бути використані для ініціації специфічної функціоналізованої організації наноструктурних блоків із точно настроєною структурною геометрією та контрольованими напівпровідниковими характеристиками. Такі методи налаштування включають мікрофлюїдику, молекулярну модифікацію, хімічні та фізичні методи осадження з пароподібного стану, збірний стратегічний метод одночасного укладання, а також використання зовнішнього електромагнітного поля.

3. Залучення теорії молекулярної щільності («density molecular theory») показало, що великі спрямовані ароматичні амінокислотні взаємодії

\section{Література.}

1. Анцыпович С. И. Пептидно-нуклеиновые кислоты: структура, свойства, применение, стратегии и практика химического синтеза / С. И. Анцыпович // Успехи химии. - 2002. - Том 71, вип. 1. C. 81-96.

2. Минцер О. П. Стратегии поиска направлений исследований с использованием нанотехнологий / О. П. Минцер // Электроника и связь. Тематич. выпуск «Электроника и нанотехнологии». - 2010. — № 5. - С. 15-18.

3. Персонализированная медицина: перспективы использования нанобиотехнологий / Залесский В. Н., Мовчан Б. А. // Укр. мед. часопис. - 2012. 1 (27). - C. 38-42.

4. Рапис Е. Г. Самоорганизация и супермолекулярная химия пленки белка от нано - до макромасштаба / Рапис Е. Г. // Журнал технической физики. 2004. — T. 74, № 4. — С. 117-122.

5. Self-assembled organic nanostructures with metallic like stiffness / Adler-Abramovich L., Koln. Yanai I. et al. // Angew. Chem. Int. Ed. Engl. — 2010. 49 (51). - P. 9939-9942.

6. The physical properties of supramolecular peptides assemblies: from building bloke association to teleological applications / Adler-Abramovich L., Gasit E. // Chem. Soc. Rev. — 2014. - 43. P. 6881-6893.

7. Функціональні супрамолекулярні полімери / Aida T., Meijer E. W., Stupp S. I. // Science. — 2012. № 335. — P. 813-817.

8. Elementary building blocks of self-assembled peptide nanotubes / Amdursky N., Molotskii M., Gazit E. et al. // J. Am. Chem. Soc. — 2010. — № 132 (44). P. 15632-15636.

9. Dynamic microfluidic control of supramolecular peptides self-assembly / Arnon Z. A., Vitalis A., мереж, що зв'язують водень, призводять до утворення квантово замкнутих областей в органічних нанострукутрах, які лежать в основі молекулярного походження їхньої напівпровідності. Останні дослідження додатково виявили деякі фізико-хімічні особливості біоінспірованих надмолекулярних органічних напівпровідників, включаючи стійкі спектри поглинання, характерні для одновимірних квантових точок або двомірних квантових свердловин («quantum wells»), емісію фотолюмінесценції оптичних хвилеводів, залежну від температури електропровідність, а також сегнетоелектричні (п’єзо - та піроелектричні) властивості.

Leviu A. et al. // Nat. Commun. — 2016. — № 7. - P. 13190.

10. Light - emitting self-assembled peptide nucleic acid exhibit both stacking interaction and Watson-crick base pairing / Berger O., Adler-Abramovich L., LevySakin M. et al. // Nat. Nano thechonol. — 2015. № 10 (4). - P. 353-360.

11. Structure - specific intrinsic fluorescence of protein of protein amyloids used to study their kinetics of aggregation. In: Uversky V., Lynbchenko Y (Eds.) Bio Nano imaging: Protein Misfolding and Aggregation / Chan F. T., Pinotsi D., Schierle G. S. K. et al. Elsevier: New York, 2014. — P. 214-231.

12. Morphology and pattern control of phenylalanine sect-assembly via evaporative deleting / Chen J., Qin S., Wu X. et al. // ACS Nano. - 2016. — Vol. 10, № 1. - P. 832-838.

13. Bio inspired target - specific crystal ration on peptide nanotubes for ultrasensitive PB ion detection / Dela Rica R., Mendoza E., Matsui H. // Small. 2010. — № 6 (16). — P. 1753-1756.

14. $\mathrm{pH}$ - Directed aggregation to control photoconductivity of self-assembled periling bisimides / Draper E. R., Greeves B. J., Barrow M. et al. // Chem. — 2017. — № 2 (3). - P. 716-731.

15. Thermodynamic factors impacting the peptide driven selt-assembly of periling di imide Nano fibers / Eakins G. L., Gallaher J. K., Keyzers R. A. et al. J. Phys. Chem. B. — 2014. — Vol. 118, № 29. - $\mathrm{P}$ 8642-8651.

16. Nano technology: Peptides as biological semiconductors / Hauser C. A. E., Zhang S. // Nature. — 2010. — № 468. — P. 516-517.

17. Alignment of aromatic peptide tables in stony magmatic fields / Hill R. J. A., Sedcuan V. L., Allen S. et al. // Advanced Materials. - 2007. № 19 (24). — P. 4474-4479. 
18. Temperature - driven phase transformation in self-assembled diphenylamine peptide nanotubes / Heredia A., Bdikin I., Koppl S. et al. // J. Phys D: Appl. Physics. — 2010. — № 43 (46). P. 462001.

19. Organic semiconductor nano streamers and their field Emission application / Fang X. S., Bando Y., Gantam U. K. et al. // J. Mater. Chem. - 2008. № 18. — P. 509-522.

20. Expanding the nano architectural diversity through aromatic di — and tripeptide co assembly: nano structures and molecular mechanism / Guo C., Arnon Z. A., Qi R., et al. // CAN Nano. - 2016. — № 10 (9). — P. 8316-8324.

21. Light - induced Ferro electricity in bicinspired self-assembled phenylalanine nanotubes, micro tubes / Gan Z., Wu X., Zhu X., Shen J. // Angew. Chem. Int. Ed. Engl. — 2013. — № 52 (7). — P. 2055-2059.

22. Gazi E. Peptide nano structures: aromatic dipeptides light up / Gazi E. // Nat. Nano technol. — 2016. № 11. - P. 309-310.

23. Initio molecular — dynamics simulation of the lined - metal - amorphous - semiconduc for transition in germanium / Kresse G., Hafner J. Ab. // Phys. Rev. B. - 1994. - № 49. - P. 14251-14269.

24. Ostwald's rule of stage governs structure transitions and morphology of dipeptide supramolecular polymers / Levin A., Mason T. O., A-Abramovich L. et al. // Nat. Commun. — 2014. — № 5. — P. 5219.

25. Transformation of dipeptide - based organ gels into chiral crystals by cryogenic treatment / Lin X., Fei J., Wang A. et al. // Angew. Chem. Int. Ed. Engl. 2017. — Vol. 56, № 10. — P. 2660-2663.

26. Expanding the solvent chemical space for selfassembly of dipeptide nano structure / Mason T. O., Chirgadre D. Y., Levin A. et al. // ACS Nano. — 2014. — Vol. 8, № 2. — P. 1243-1253.

27. Self-assembly of phenylalanine peptide with controlled polarization for power generation / Nguyen V., Zhu R., Jen Kins K., Yang R. // Nat. Commun. 2016. — № 7. — P. 13566.

28. A label-free quantitative assay of amyloid fibril growth based on intrinsic fluorescence / Pinotsi D., Buell A. K., Dobson C. M. et al. // Chem Bio. Chem. - 2013. - № 14. - P. 846-850.

29. Proton transfer and structure - specific fluorescence in hydrogen bond - rich protein structures / Pinotsi D., Grisanti L., Mahou P. et al. // J. Amer. Chem. Soc. - 2016. — Vol. 138, № 9. — P. 3046- 3057.

30. Casting metal nanowires within discrete selfassembled peptide nano tubles / Reches M., Gazit E. // Science. - 2003. — № 300. — P. 625-627.

31. Santhanamoozthi N. Diphenylalanine peptide nano tube: charge transport, band gap and its relevance to potential biomedical application / Santhanamoozthi N. // Adv. Mat. Lett. — 2011. — № 2. — P. 100-105.
32. Uncovering the design rules for peptide synthesis of metal nano particles / Tan Y. N., Lee J. Y., Wang D. K. // J. Am. Chem. Soc. — 2010. — № 132. — P. 5677-5686.

33. F moc-modified amino acids and short peptides: simple bio-inspired building blocks for the fabrication of functional materials / Tao K., Levin A., Adler A. L. et al. // Chem. Soc. Rev. — 2016. — № 45. P. 3935-3953.

34. Self-assembling peptide semiconductors / Tao K., Makam P., Aizen R. et al. // Science. - 2017. № 358 (6365). — P. 9756.

35. Dissolution and degradation of F moc-diphenylalanine self-assembled gels desalts in necrosis at high concentrations in vitro / Trung W. T., Su Y., Gloria D. et al. // Biomater. Sci. — 2015. — № 3. — P. 298-307.

36. Functional supramolecular materials: self-assembly of phthalocyanines and porphyrins / Van Nostrum C. F., Nolte R. J. M. // Chem. Commnn. — 1996. P. 2385-2392.

37. Vertically aligned peptide nano structures using plasma enhanced chemical vapor deposition / Vasuden M. C., Kocruner H., Singh K. M. et al. // Biomacromolecules. — 2004. — Vol. 15, № 2. P. 533-540.

38. Self-assembly of hexagonal peptide micro tubes and their optical waveguide / Yan X., Li J., Mohwald N. // Adv. Mater. — 2011. — № 23. — P. 2796-2801.

39. Uniaxial oriented peptide crystals for active magical waveguiding / Yan X., Su Y., Li J. et al. // Angew. Chem. Int. Ed. Engl. — 2011. — Vol. 50, № 47. — P. 11186-11191.

\section{References.}

1. Antsypovich, S. I. (2002). Peptidno-nukleinovyye kisloty: struktura, svoystva, primeneniye, strategii i praktika khimicheskogo sinteza [Peptide-nucleic acids: structure, properties, application, strategies and practice of chemical synthesis]. Uspekhi khimii (The success of chemistry), 71 (1), 81-96. [In Russion].

2. Mintser, O. P. (2010). Strategii poiska napravleniy issledovaniy s ispol'zovaniyem nanotekhnologiy [Strategies for Searching Research Directions Using Nanotechnology]. Elektronika i svyaz'. Tematich. vypusk «Elektronika i nanotekhnologii» (Electronics and communications. Thematic. issue «Electronics and Nanotechnology»), 5, 15-8. [In Russion].

3. Zalessky, V. N., Movchan, B. A. (2012). Personalizirovannaya meditsina: perspektivy ispol'zovaniya nanobiotekhnologiy [Personalized medicine: prospects for the use of nanobiotechnology]. Ukr. med. chasopis (Ukr. med. chronicle), 1 (27), 3842. [In Russion].

4. Rapis, E. G. (2004). Samoorganizatsiya i supermolekulyarnaya khimiya plenki belka ot nano — do makromasshtaba [Self-organization and 
supermolecular chemistry of a protein film from nano to macroscale]. Zhurnal tekhnicheskoy fiziki (Journal of Technical Physics), 74 (4), 117-22. [In Russion].

5. Adler-Abramovich, L., Koln., Yanai, I. et al. (2010). Self-assembled organic nanostructures with metallic like stiffness. Angew. Chem. Int. Ed. Engl., 49 (51), 9939-42.

6. Adler-Abramovich, L., Gasit, E. (2014). The physical properties of supramolecular peptides assemblies: from building bloke association to teleological applications. Chem. Soc. Rev., 43, 6881-6893.

7. Aida, T., Meijer, E. W., Stupp, S. I. (2012). Functional supramolecular polymers. Science, 335, 813-7.

8. Amdursky, N., Molotskii, M., Gazit, E. et al. (2010). Elementary building blocks of self-assembled peptide nanotubes. J. Am. Chem. Soc., 132 (44), 15632-36.

9. Arnon, Z. A., Vitalis, A., Leviu, A. et al. (2016). Dynamic microfluidic control of supramolecular peptides self-assembly. Nat. Commun., 7, 13190.

10. Berger, O., Adler-Abramovich, L., Levy-Sakin, M. et al. (2015). Light - emitting self-assembled peptide nucleic acid exhibit both stacking interaction and Watson - crick base pairing. Nat. Nano thechonol., 10 (4), 353-60.

11. Chan, F. T., Pinotsi, D., Schierle, G. S. K. et al. (2014). Structure - specific intrinsic fluorescence of protein of protein amyloids used to study their kinetics of aggregation. In: Uversky V., Lynbchenko Y (Eds.) Bio Nano imaging: Protein Misfolding and Aggregation. Elsevier: New York.

12. Chen, J., Qin, S., Wu, X. et al. (2016). Morphology and pattern control of phenylalanine sect-assembly via evaporative deleting. ACS Nano, 10 (1), 832-8.

13. Dela Rica, R., Mendoza, E., Matsui, H. (2010). Bio inspired target- specific crystal ration on peptide nanotubes for ultrasensitive PB ion detection. Small, 6 (16), 1753-6.

14. Draper, E. R., Greeves, B. J., Barrow, M. et al. (2017). $\mathrm{pH}$-Directed aggregation to control photoconductivity of self-assembled periling - bisimides. Chem., 2 (3), 716-31.

15. Eakins, G. L., Gallaher, J. K., Keyzers, R. A. et al. (2014). Thermodynamic factors impacting the peptide - driven selt-assembly of periling di imide Nano fibers. J. Phys. Chem. B., 118 (29), 8642-51.

16. Hauser, C. A. E., Zhang, S. (2010). Nano technology: Peptides as biological semiconductors. Nature, 468, 516-7.

17. Hill, R. J. A., Sedcuan, V. L., Allen, S. et al. (2007). Alignment of aromatic peptide tables in stony magmatic fields. Advanced Materials, 19 (24), 4474-9.

18. Heredia, A., Bdikin, I., Koppl, S. et al. (2010). Temperature - driven phase transformation in selfassembled diphenylamine peptide nanotubes. J. Phys D: Appl. Physics., 43 (46), 462001.
19. Fang, X. S., Bando, Y., Gantam, U. K. et al. (2008). Organic semiconductor nano streamers and their field Emission application. J. Mater. Chem., 18, 509-22.

20. Guo, C., Arnon, Z. A., Qi, R. et al. (2016). Expanding the nano architectural diversity through aromatic di-and tripeptide co assembly: nano structures and molecular mechanism. CAN Nano, 10 (9), 8316-24.

21. Gan, Z., Wu, X., Zhu, X., Shen, J. (2013). Light induced Ferro electricity in bicinspired self-assembled phenylalanine nanotubes, micro tubes. Angew. Chem. Int. Ed. Engl., 52 (7), 2055-9.

22. Gazi, E. (2016). Peptide nano structures: aromatic dipeptides light up. Nat. Nano technol., 11, 309-10.

23. Kresse, G., Hafner, J. Ab. (1994). Initio moleculardynamics simulation of the lined - metal - amorphous - semiconduc for transition in germanium. Phys. Rev. B., 49, 14251-69.

24. Levin, A., Mason, T. O., A-Abramovich, L. et al. (2014). Ostwald's rule of stage governs structure transitions and morphology of dipeptide supramolecular polymers. Nat. Commun., 5, 5219.

25. Lin, X., Fei, J., Wang, A. et al. (2017). Transformation of dipeptide - based organ gels into chiral crystals by cryogenic treatment. Angew. Chem. Int. Ed. Engl., 56 (10), 2660-3.

26. Mason, T. O., Chirgadre, D. Y., Levin, A. et al. (2014). Expanding the solvent chemical space for self - assembly of dipeptide nano structure. ACS Nano, 8 (2), 1243-53.

27. Nguyen, V., Zhu, R., Jen Kins, K., Yang, R. (2016). Self-assembly of phenylalanine peptide with controlled polarization for power generation. Nat. Commun., 7, 13566.

28. Pinotsi, D., Buell, A. K., Dobson, C. M. et al. (2013). A label-free quantitative assay of amyloid fibril growth based on intrinsic fluorescence. Chem Bio. Chem., 14, 846-50.

29. Pinotsi, D., Grisanti, L., Mahou, P. et al. (2016). Proton transfer and structure - specific fluorescence in hydrogen bond - rich protein structures. J. Amer. Chem. Soc., 138 (9), 3046-57.

30. Reches, M., Gazit, E. (2003). Casting metal nanowires within discrete self-assembled peptide nano tubles. Science, 300, 625-7.

31. Santhanamoozthi N. (2011). Diphenylalanine peptide nano tube: charge transport, band gap and its relevance to potential biomedical application. Adv. Mat. Lett., 2, 100-105.

32. Tan, Y. N., Lee, J. Y., Wang, D. K. (2010). Uncovering the design rules for peptide synthesis of metal nano particles. J. Am. Chem. Soc., 132, 5677-86.

33. Tao, K., Levin, A., Adler, A. L. et al. (2016). F moc-modified amino acids and short peptides: simple bio-inspired building blocks for the fabrication of functional materials. Chem. Soc. Rev., 45, 3935-53. 
34. Tao, K., Makam, P., Aizen, R. et al. (2017). Selfassembling peptide semiconductors. Science, 358 (6365), 9756.

35. Trung, W. T., Su, Y., Gloria, D. et al. (2015). Dissolution and degradation of F moc- diphenylalanine self-assembled gels desalts in necrosis at high concentrations in vitro. Biomater. Sci., 3, 298-307.

36. Van Nostrum, C. F., Nolte, R. J. M. (1996). Functional supramolecular materials: self-assembly of phthalocyanines and porphyrins. Chem. Commnn., 2385-92.
37. Vasuden, M. C., Kocruner, H., Singh, K. M. et al. (2004). Vertically aligned peptide nano structures using plasma enhanced chemical vapor deposition. Biomacromolecules, 15 (2), 533-40.

38. Yan, X., Li, J., Mohwald, N. (2011). Self-assembly of hexagonal peptide micro tubes and their optical waveguide. Adv. Mater., 23, 2796-801.

39. Yan, X., Su, Y., Li, J. et al. (2011). Uniaxial oriented peptide crystals for active magical waveguiding. Angew. Chem. Int. Ed. Engl., 50 (47), 11186-91. 